plane, for the horns of the crescent come into focus a little before the centre.

From serial drawings of this kind it is possible to construct a thread model showing the course of the rays from one focal line to the other. A small perspective representation of it would serve no useful purpose, but the model can easily be made by anyone interested, as follows. On a base-board draw the curved focal line $B$; drill seventeen holes in it, $a, b, c \ldots i \ldots o, p, q$, at equal intervals apart, the hole $i$ being at the vertex of the curve. Next, on a narrow strip of wood draw a straight line parallel to its length and drill nine holes $1,2,3 \ldots 7,8,9$, at equal intervals along the line. Fix this rod at a convenient height above the baseboard so that it lies over the axis of the curve, the end 1 being inclined downward over the concave side. The holes are now to be joined by threads according to the following scheme :

$$
\begin{array}{lllllllllllllllll}
a & b & c & d & e & f & g & h & i & j & k & l & m & n & o & p & q \\
9 & 8 & 7 & 6 & 5 & 4 & 3 & 2 & 1 & 2 & 3 & 4 & 5 & 6 & 7 & 8 & 9 \\
1 & 2 & 3 & 4 & 5 & 6 & 7 & 8 & 9 & 8 & 7 & 6 & 5 & 4 & 3 & 2 & 1
\end{array}
$$

in which the holes in the same column are to be joined. (If the joins to the points in the latter half of the last line are omitted, a better view can be had of the threads in the interior of the model.) Crosssections of this model by imaginary horizontal planes will be found to reproduce the appearances seen under the microscope.

But to return to the observations themselves. On rotating the crystal into positions such that the refracted rays approach nearer and nearer to the optic axis, and making observations in depth at each position, it is seen that the focal line $A$ (represented by successive positions of the faint spot of light) continues to turn over, until, when the optic axis is reached, it is parallel to the axis of the microscope. We then see that the light giving rise to the Hamiltonian conical refraction does not proceed from a point (as most descriptions of the phenomenon lead one to suppose) but emanates from a focal line : the bright central spot is this focal line seen end on.

Sir George Stokes supplied the mathematical theory underlying the effects observed by Sorby, and after considering the case of rays in the $r z$-plane he concludes : "The extravagant changes of apparent index in the immediate neighbourhood of the wave- and ray-axes could probably not well be followed by the microscope, on account of the necessity of working with pencils of finite angular aperture, which would make the phenomena of focusing blend themselves with those of conical refraction" ". Observation shows that this is true; and that it is also true far away from the neighbourhood of the optic axes; so that it is impossible to draw any but an arbitrary distinction between the Hamiltonian conical refraction in the neighbourhood of the optic axes and that taking place elsewhere in the optic axial plane.

After determining refractive indexes of aragonite to five places of decimals by the prism method, Glazebrook formed the opinion that it is "most probable that Fresnel's theory is only true as a first approximation", and "we may assert that in a central section of the wave-surface inclined at a small angle to the plane of the optic axes, there is a considerable difference between Fresnel's theory and experimen't : that the differences between the two are most marked in the neighbourhood of the optic axes, and amount there to 0.0005 about"s.
It is in this region near the optic axial plane that Sorby's method also indicates departures from Fresnel's wave-surface, for as Stokes noted: "Mr. Sorby's method is remarkable for this, that it brings out into prominence variations of refraction with change of direction, though the absolute refractions which are involved may be nearly the same"'. Unfortunately, these differences cannot be determined quantitatively beyond three places of decimals by this method, even when the focal line lies wholly in one plane.

Rays travelling in the $y \%$-plane also form curved focal lines.

The problem of deducing the form of the wavesurface from the shape of the focal lines is evidently a formidable one, for even Stokes, owing to the mathematical difficulties involved, did not deal with such a line throughout its whole length, but only with one point in it, namely its point of intersection with a principal section of the wave-surface.

1 Melmore, S., NATURE, 150, 382 (1942).

2 Stokes, G. G., Proc. Roy. Soc., 26, 386 (1878).

${ }^{3}$ Glazebrook, R. T., Phil. Trans. Roy. Soc., 170, 287 (1879).

\section{A NEW ELECTRICAL FREQUENCY DIVIDER}

NE of the common characteristies of all nonlinear electrical devices, such as vacuum tub s, is the generation of harmonic frequencies in which, with a pure sine wave input, the output contains a series of multiples of the input frequency. For more than a decade, piezo-electric oscillators have been used as sources of reference frequencies because of their high stabllity. Since it is desirable to operate these oscillators at a frequency higher than those of the standards-usually at 100 ke.-a sub-multiple generator, or frequency divider, is required to secure the desired lower frequencies.

The most successful frequency dividing circuit is the regenerative frequency divider, the basic form of which is described in an article by F. R. Stan el (Bell Lab. Rec., 21, No. 4; Dec. 1942). It consists of a modulator, an output circuit tuned to the submultiple frequency to be produced, and a harmonic generator. The action of the circuit is easy to understand. Assume, for example, that the input frequency is $100 \mathrm{kc}$, and that the output is $20 \mathrm{kc}$. Part of the output is fed back to the harmonic generator, where its fourth harmonic, $80 \mathrm{kc}$., will ke selected by a tuned circuit. This $80 \mathrm{kc}$. current and the $100 \mathrm{kc}$. input will result in a difference frequency of $20 \mathrm{kc}$. in the output of the modulator, and in a number of other frequencies as well. The $20 \mathrm{kc}$. output frequency is selected by the tuned circuit. To start the oscillators, a $20 \mathrm{kc}$. component must be present in the circuit. In some regenerative frequency dividers this is supplied by a pulse applied from a starting circuit, but in more recent circuits the starting circuit has been omitted and dependence is placed upon the transient voltages normally present in the circuit for this starting pulse.

In general, when the $n$th sub-multiple frequency is desired, the harmonic generator is tuned to the $(n-1)$ th harmonic. When the output frequency is to be half the input frequency, $(n-1)$ is equal to 1 , and no harmonic generator is required. Part of the output is fed back directly to th e modulator.

The regenerative frequency generator cannot 
operate without an input frequency. Should the input frequency fail, the output drops to zero, and thus off-frequency operation does not occur. In addition, the output current of the generator is a relatively pur 3 sine wave, and additional 'clean-up' filters are not required as they are with the multivibrator when a sine wave is desired. A pentagridmixer tube is used for the modulator and a pentode for the harmonic generator. With a modulator tube having two shielded input grids, it is possible to eliminate the balanced modulators and transformers required for earlier regenerative frequency dividers. With the increased modulator gain obtained, not only is it possible to eliminate the starting circuit, but also frequency division as great as 10 to 1 is obtainable in one stage.

\section{FORTHCOMING EVENTS}

(Meeting marked with an asterisk * is open to the public)

Saturday, May 29

Free German Instrutute of Science and Learning (at 16 Buckand Crescent, London, N.W.3), at 5 p.m. - Capt. Helmer Dahl:
"Norwegian Universities and Schools-Past, Present and Future".

Monday, May 31

FARMers' Crub (at the Royal Empire Society, Craven Street, Strand, London, W.C.2), at 2.30 p.m.-Mr. F. A. Secrett: "Horticulture in Peace and War".

\section{Friday, June 4}

Physical Society (in the Lecture Theatre of the Science Museum, Txhibition Road, South Kensington, London, S.W.7), at 5 p.m.Prof. F. C. Bartlett, F.R.S.: "Some Current Problems in Visual

ROYAL INSTITUTION (at 21 Albemarle Street, London, W.1), at 5 p.m.-Mr. Arthur Bryant: "Our Sea Traution".

\section{Saturday, June 5} Associarion For ScIEnTIFIC Photography (at the Royal Institu-
tion, 21 Albemarle Street, London, W.1), at 4 p.m.-Prof. J. Yule tion, 21 Albemare Street, London, W.1) at 4 p.m. CProf "Indirect Bogue : "Applied Photography"”; Miss, K. C. Clark: "Indirect Radiography as applied to Medical Work" ; Dr. L. Mullins: "MisReyersbach: "Sub-Standard Kine-Photomicrography"; Mr. C. M. M. Reyersbach: "Sub-Standard Kine-Photomicrography"; Mr., H. M. M.
Ross: "The Photography of Photo-Elastic Stress Patterns"."

\section{APPOINTMENTS VACANT}

APPLICATIONS are invited for the following appointments on or before the dates mentioned:

Leoturar In Enginmering SubJeots in the Durham Road Senior Technical and Commercial Institute-The Director of Education, RESIDENT LECTURER IN SOIENOE, able to take Gardening-The Principal, Diocesan Training College, Fishponds, Bristol (June 5).

LeCTuRer to teach Electrical EngINEering SubJects in the Municipal Technical College-The Director of Education, Education Offices, Nelson Square, Bolton (June 5).

Pharmacist at the County Hospital, Pembury, Tunbridge WellsThe County Medical Officer, County Hall, Maidstone (June 7).

PrincIPAL of the South-East Essex Technical College, DagenhamThe Chief Education Officer, County Offices, Chelmsford (June 12).

Psychiatric Soclal Worker to work with the Psychiatrist and Educational Psychologist in the Child Guidance Clinic-The Chief Education Officer, Education Ofice, Warrior Square, Southend-on-Sea (June 21).

CrTY Bacteriologrst—The Town Clerk, Municipal Buildings, Dale une 30 ).

Chief Technical Assistant, Senior Technidal Assistant, and TEChNICAL ASSISTANT I, FOR ENGINEFRs experienced in the use of Woodworking Machine Tools or Production Managers experienced in Planning the Production of Machined Woodwork-The Ministry of Labour and National Service, Central (Technical and Scientific)
Register (Ref. C.1068), Alexandra House, Kingsway, London, W.C.2. BIOLOGY TEACHER (part-time) to assist in Botany and ZoologyThe Director of Edueation, The Polytechnic, 309 Regent Street, London, W.1.

\section{REPORTS and other PUBLICATIONS (not included in the monthly Books Supplement) Great Britain and Ireland}

Scientiflc Proceedings of the Royal Dublin Society. Vol. 23 (N.S.), No. $9:$ Salmon and Sea Trout of the Waterville (Currane) River. By Arthur E. J. Went and T, Sankey Barker. Pp. 83-102. (Dublin: Hodges, Figgis and Co., Ltd.; London: Williams and Norgate,
Ltd.) 2 . $6 d$.

Report of the Rugby School Natural History Society for the Year 1942. (Seventy-sixth Issue.) Pp. 22. (Rugby : George Over, Ltd.) [124 University of London: University College. Annual Report, Feb. ruary 1942-February 1943. Pp. 64. (London: Taylor and Francis,
Ltd.)

British Records Association. Memorandum No. 7 : Modern Records, What nay we Destroy? Pp. 6. (London: British Records Association, c/ o Public Record Office.) (London: British Records AssociaReport of the Committee on Post-War Agricultural Education in England and Wales. (Cmd. 6433.) Pp. 92. (London: H.M. Stationery Office.) 1s. $6 d$. net.

ionery
[134
ns for

The Pre-Nursing Course : Synopsis of Regulations, Suggestions for Syllabuses, Equipment and Books : together with further Recommendations of the Association of Women Science Teachers. Pp. 20,
(London: John Murray.) 9d.

National Institute of Economic and Social Research. Annua Report, 1942. Pp. 12, (London: National Institute of Economic eud Social Research.) (194

\section{Other Countries}

Records of the Geological Survey of India. Vol. 77, Professional Paper No. 1: Report on Sodium Salts in Reh Soils in the United Provinces, with Notes on Occurrences in other parts of India. By J. B. Auden, B. C. Gupta, P. C. Roy and Mehdi Hussain. Pp. ii +45.
(Calcutta : Geological Survey of India.) 14 annas; 18.3 .
[124 Indian Forest Records (New Series), Utilisation, Vol. 2, No. 8: The Testing and Suitability of Indian Timbers for Plywood Tea Chests. By V. D. Limaye and Sultan Mohammed. Pp. v $+179-190+4$ plates. 9 annas; $10 d$. Entomology, Vol. 7, No. $2:$ On Some Indian (Delhi : Manager of Publications.)

Smithsonian Institution. War Background Studies, No. 9: The Native Peoples of New Guinea. By M. W. Stirling. (Publication 3726.) Pp. vi $+25+28$ plates. (Washington, D.C.: Smithsonian Institu-
tion.)

Ministry of Finance, Egypt: Survey of Egypt. Egypt in the Classical Geographers. By the late Dr. John Ball. Pp. vi $+185+8$ plates. (Cairo: Government Press.) 750 mills. Proceedings of the Academy of Natural Sciences of Philadelphia. Vol. 94, 1942. Pp. iii $+408+27$ plates. (Philadelphia: Academy of Indian Forest Bulletin No. 108: Manufacture of Newsprint, Cheap Indian Forest Bulletin No. 108: Manufacture of Newsprint, Cheap
Papers and Boards. (Interim Report on the Investigations carried out at the Forest Research Institute, Dehra Dun.) By M. P. Bhargava and $S$, Kartar Singh. Pp. iii +15 . (Delhi : Manager of Publications.)

Imperial Council of Agricultural Research. Studies on Fruit and Vegetable Products. 1: Canning of Apricots in Baluchistan. By Dr. G. S. Siddappa. Pp. ii $+18+1$ plate. 1.4 rupees; $2 s .2:$ Drying of Grapes in Baluchistan. By Dr. G. S. Siddappa. Pp. $11+14+1$ plate.
12 annas; 18. (Delhi : Manager of Publications.) 2 annas ; 18. (Delhi : Manager of Publications.) Art. 12: A Revision of the Rotatorian Genus Keratelli with De. scriptions of Three New Species and Five New Varieties. By Elbert H. Allstrom. Pp. 411-457+plates 35-42. (New York : American Museum Proceedings of the United States National Museum. Vol. 93, No. Proceedings of the United States National Museum. Vol. 93, No.
3160: Skeletal Remains with Cultural Associations from the Chicama Moche and Virú Valleys, Peru. By T. D. Stewart. Pp. 153-186+ Moche and Virú Valleys, Peru. By T. D. Stewart. Pp. 153-186+
plates 11-18. Vol. 93, No. 3161: New Marine Mollusks from the plates 11-18. Vol. 93, No. 3161 : New Marine Mollusks from the Antillean Region. By Harald A. Behder. Pp. 187-204+plates 19-20. Vol. 93, No. 3163 : Osteology of Upper Cretaceous Lizards from Utah, with a Description of a New Species. By Charles W. Gilmore. Pp.
209-214. (Washington, D.C.: Government Printing Office.) [164

South African Journal of Science. Vol. 39: Being the Report of the Fortieth Annual Meeting of the South African Association for the Advancement of Science, Johannesburg, 1942, 29th June to 1st July. Pp. xviii +387 . (Johannesburg: South African Association for the Advancement of Science.) 308. net. University of Cape Town. Communications from the School of
African Studies, New Series, No. $7:$ The Bored Stones of Southern Africa, Part 3: South Eastern, Thirstland, Karoo, and Southern Forests Regions. By A. J. H. Godwin. Pp. ii + 27. (Cape Town: Torests Regions. By A. J. H. Godwin. Pp. iii 27. (Cape Town
The University.) The National Academy of Peiping during the Period of Years 1037-42. Pp. 14. (Kunming: National Academy of Peiping.) [16 Dominion Observatory. Bulletin No. R27: Report for the Year ended 31st December 1941. Pp. 2. (Wellington: Government Printer.)

U.S. National Museum. Bulletin 180: Fishes of the Phœnix and Samoan Islands collected in 1939 during the Expedition of the U.S.S. Bushnell. By Leonard P. Schultz. Pp. $x+316+9$ plates. (Washington,

Smithsonian Miscellaneous Collections. Vol. 103, No. 9: Mystacocarida, a New Order of Crustacea from Intertidal Beaches in Massachusetts and Connecticut. By Robert W. Pennak and Donald J. Zinn. (Publication 3704.) Pp. $1 \mathrm{i}+11+2$ plates. (Washington, D.C.:
Smithsonian Institution.) 